\title{
Perceiving Migration in Emirdağ: A Baudrillardian Perspective
}

\author{
Filiz Göktuna Yaylacı, Anadolu University, Turkey \\ Mine Karakuş, Anadolu University, Turkey
}

\begin{abstract}
By 1970s, Western societies have entered a new phase marked by a cultural, economic and political transformation. These transformations in the economic realm as decrease in the demand on human labor and flexibility in the mode of production also have serious implications on the social, cultural and political areas, particularly on the volume and the nature of migratory flows. Post-modern school of thought provides the basis for the most of the arguments on the fore mentioned economic restructuration and its implications on contemporary social phenomena. The macro level theories that explain the labor migration from East to West and from South to North in the Fordist era, fall short in elaborating the multi-faceted flows of different forms of migration. Desires for different life style and opportunities, the images of the receiving societies and how the actors perceive the destined lands, play important roles in individual choices for migration. These images and information of various forms and kind are conveyed through mass media and Internet, which shape the perceptions and identity formation of the prospective migrants. From this standpoint, the main aim of this paper is to analyze the role and the way that perceptions, aspirations and images play in actors' decision making for migration. Within this context, by employing Baudrillard's conceptual framework, it will be argued that, in the universe of simulations, migration and factors of migration become hyperrealities and images that have lost their realities. By referring to Baudrillard's concepts of simulacrum and simulation, it is intended to explicate whether or not and how perceptions, desires, images constructed by individuals stimulate migration. Within this context, the impact of direct personal communications, the communication with symbols through material ownerships, and the impact of perceptions of material symbols on individuals will be analyzed. Furthermore, how these perceptions effect the decision making process for migration will be elaborated. For that purpose, an explorative research was conducted in Emirdağ district and its surrounding villages. Emirdağ used to be an important source of labor migration up until 1970s, still continues to be a major source of migration in the form of chain migration especially to Belgium even though economic labor migration to European countries has been halted for last three decades. In order to
\end{abstract}


understand the main motives of the individuals and how the receiving societies are being perceived and the images of the receiving lands are being constructed by the actors of migration in the town, a series of semi-structured in-depth interviews are conducted with 44 participants, 24 women and 20 men from Emirdağ and its periphery.

Keywords: Inter-cultural communication, interaction of inter-group communication, simulacra, migrant imagination, life opprtunities 


\section{Introduction}

By the 1970 s especially in the western societies, cultural, economic and social changehave entered a new phase. This process corresponds to the emergence of the postmodern thought which has an impact on most of contemporary debates. At present, the instrumental rationality, universality, grand theories, reality and universal moral understanding of modernity is replaced by locality, the refusal of grand theories, subjectivity, deconstruction (Derrida), power and discourse (Foucault), and language games (Lyotard) of postmodernity. On the basis of collage, diversity, pluralism phenomenon the postmodern discourse was formed around the denial of all de facto propositions, language games, acceptance of plurality and diversity by scientists; application of linguistic transformation that opens the understanding o reality and truth to discussion, objecting to the hegemony of absolute truth (Kumar, 2010, Sarup, 2010, Rosenau, 2004). In this discourse what is important is no longer the question of truth but rather how truth is constructed. General moral understandings and principals have lost their legitimacy; now the sources of the moral principals are the living circumstances and the necessities of our current age.

The macro level theories that explain the dynamics of migration, have evaluated the roles of production, distribution, the state policies. However, today, it is strongly emphasised that the decisiveness of the interaction that cross passes the national boundaries has increased; the cultural corridors and migration patterns have created trans-national societies; the interpersonal solid ties are replaced by a more mobile and fluid ones, the metaphor of "fluidity" becomes more functional in understanding our contemporary world (Bilgin, 2007: 20; İlhan, 2013: 236). Nowadays, for the start and continuation of many of the migratory movements, the role and impact of information, social and cultural capital, individual perceptions and experiences are highlighted (Castells and Miller, 2008: 37). Informal webs constitute, personal relations, family and household patterns, friend and community ties, mutual help in within social and economic issues (Castells and Miller, 2008: 37). In the process of face-to-face communication constructed around the webs of migration and shaped by the expedition and exchange of symbolic goods and symbols, in the societies of origin, a reality of the destined lands is being constructed through the narratives and goods. It could be asserted that, this reality and the perception, shape the tendencies to migrate as well as the views for migration of individuals in the societies of origin who haven't migrated yet. 


\section{Simulacra, Simulation and Migration within Baudrillardia Framework}

For elucidating the efficiency of the consumer society debates in explaining the current social order, it could be referred to Baudrillard and his conceptualization of signs and images. Having the opinion that the consumer goods are the system of signs that differentiate the society, Baudrillard takes consumption as the consumption of signs rather than the use value (Sarup, 2010: 230, Baudrillard, 2015). Baudrillard evaluates the transition from modernity to post-modernity as a historical scheme such as early modernity, modernity and postmodernity (Sarup, 2010: 228, Baudrillard, 2015). Within this historicity, he writes about simulacra, which have no relation with anything except its own, self and mentions three phases of simulacra. (Baudrillard, 2014: 158-165; Baudrillard, 2008; Sarup, 2010: 228, Adanır, 2010, Aydoğan et. al., 2005, Öker, 2005). The first one is the Law of Natural Value that encompases the era between the Renaissance and the Industrial Revolution. The form that designates this era is duplication. It is being stated that, the duplication of reality is remained at the art level such as painting, sculpture, theatre, (Baudrillard, 2008: $\mathrm{x}-\mathrm{xi}$ ).

The dominant form of the second phase of Industrialisation was production and the simulacrum of this stage was the Law of Commodity exchange value. In this phase production that was materialised by machinary were the simulacra, and the reproduction of the reality were shifted to movies, photography and the production of Industrial simulacra were in the form of mass production based on technology (Baudrillard, 2008: 97; Aydoğan et. al., 2005). In the third phase identified by "Code" the dominant form is simulation (Baudrillard, 2008: x-the translator's Forword; Aydoğan et. al., 2005). In this stage the simulacra are determined according to their Law of structural sign value and replace the hiper-reality. The goods are replaced by simulacra, which are the images that are to be percieved as reality, codes and simulations which are described as images that replace reality. What is important now is the images that took place of goods. From this standpoint, the organization of social life is around consumption and what is consumed are the images. In this capitalist development, production left its place to consumption and image and this destroys the reality. For instance mobile phones are far away from its original function of communication and become an image that are "connecting people". What is important is not the need for a phone but the desire fort he simulation that replaced the phone, in other words, they consume the image of the brand. This is very similar to Disneyland: the material goods become vague and blurry in a universe that is surrounded by delusive colors and visions. 
Accordingly, a system of signs as simulacras has come into being which are independent of materials. In parallel with this, social relations also are carried out through images, symbols and brands.

Baudrillard mentions in his book The Transparency of Evil that we have passed from the third stage to the fourth stage of fractal stage. The definition of fractal stage as the contemporary scheme of our culture in his own words (Baudrillard, 1995: 11-12): "For after the natural, commodity and structural stages of value comes the fractal stage. The first of these stages had a natural referent, and value developed on the basis of a natural use of the world. The second was founded on a general equivalence, and value developed by reference to logic of the commodity. The third is governed by code, and value develops here by reference to a set of models. At the fourth, the fractal (or viral, or radiant) stage of value, there is no point of reference at all, and value radiates in all directions, occupying all interstices, without reference to anything whatsoever, by virtue of pure contiguity. At the fractal stage there is no longer any equivalence, whether natural or general. Properly speaking there is now no law of value, merely a sort of epidemic value, a sort of general metastasis of value, a haphazard proliferation and dispersal of value. Indeed, we should really no longer speak of value at all, for this kind of propagation or chain reaction makes all valuation impossible. Once again we are put in mind of microphysics: it is as possible to make estimations between beautiful and ugly, true and false, or good and evil, as it is simultaneously to calculate a particle's speed and position. Good is no longer the opposite of evil, nothing can now be plotted on a graph or analysed in terms of abscissas and ordinates. Just as each particle follows its own trajectory, each value or fragment of value shines for a moment in the hevans of simulation, and then disappears into the void along a crooked path that only rarely happens to intersect with other such paths. This is the pattern of fractal and hence the current pattern of our culture". (Baudrillard, 1995: 11-12; http://www.teoretisketirsdage.net/files/gimgs/Baudrillard\%20-

\%20After\%20the\%200rgy\%20-\%20Transaestetics.pdf)

In defining the fractal stage Baudrillard uses the term After the Orgy. In this context Baudrillard declares that modernity and all the meaningful goals of the processes that are believed to emerge with modernity have been reached and at this stage of satisfaction the relations with reality have been disrupted (Baudrillard, 1995: 10): "If we were to characterize 
the present state of affairs, I would describe it as 'after the orgy'. The orgy in question was the moment when modernity exploded upon us, the moment of liberation in every sphere. POlitical liberation, sexual liberation, liberation of the forces of production, liberation of the forces of destruction, women's liberation, children's liberation, liberation of unconscious drives, liberation of art. The assumption of all models of representation, as of all models of anti representation. This was a total orgy. We have pursued every avenue in the production and effective overproduction of objects, signs, messages, ideologies and satisfactions. Now everything has been liberated, the chips are down, and we find ourselves faced collectively with the big question: What do we do now the orgy is over? Now all we can do is simulate the orgy, simulate liberation. We may pretend to carry on in the same direction, accelerating but in reality we are accelerating in a void because all the goals of liberation are behind us (Baudrillard, 1995: 10).”

The above-mentioned state is a state of simulation; all scenarios real or virtual have occurred so nothing left to do except replaying the already occurred scenarios. The reason for continuous reproduction is that the signs and practices are liberated from their ideas, concepts, essence, values, referents, roots and goals. Idea has already disappeared but things continue to process. The liberation started with modernity while reaching its goal, everything that liberated beyond its envisaged level liberated to enter the sheer cycle (Baudrillard, 1995; Adanır, 2010, Aydoğan et. al., 2005, Öker, 2005). Even though all utopias are substantiated, oddly enough, there is nothing left to do but act as if they haven't been substantiated yet (Baudrillard, 1995). The idea of development has disappeared but development continues. The idea of prosperity as the basis of production has disappeared but production continues. In the realm of politics idea has disappeared but game of politics with its own goals continues in a secret recklessness. Nothing disappears by coming to an end or dying; but disappears by rapid reproduction, extensionally, by way of satisfaction and transparancy; there is a diffusion in the form of fractal (Baudrillard, 1995, s.13).

Within this theoretical framework the constructed reality in the course of the migration process in general and the process of migration from Emirdağ to Europe in particular can be explained by, for example, Baudrillard's analogy of Disneyland. With the existence of all kinds of games and toys Disneyland entertain individuals in a fantastic universe, while this hides the fact that the world outside of Disneyland which is believed to be the real is 
deceptive, what is perceived to be real belongs to the universe of simulation (Baudrillard, 2014: 26; Jacobi, http://essex.ac.uk/sociology/documents/pdf/ug_journal/vol7/2012SC224_ ChristopherJacobi_FINAL.pdf Date: 28.31.2015.). Disneyland as a fictituous world is there to prove that the outside world is real and the underlying idea that Disneyland is to be so dreamy is to make people believe that the outside world is real. Whereas Baudrillard argues that California surrounding Disneyland doesn't belong to the reality but belongs to the simulation World (Jacobi, http://essex.ac.uk/sociology/documents/pdf/ug_journal/vol7/ 2012SC224_ChristopherJacobi_FINAL.pdf Date: 28.31.2015). The main thesis of this article, in paralel to this analogy, everything in the simulation world has disappeared but continues to act as if they still exist such as the process of migration and the idealization of Europe as one of the sources of migration Migration as we know is in fact disappeared, migration to different cultures are not possible anymore since the cultures become homogenic like everything else. At the same time, the process of migration should seem to be continuing, the undocumented migrants should die in the Mediterranean, anti-migration laws should pass in order to pretend that the idealized Europe still exist and the idea that Europe is worth to migrate continues.

From Baudrillardian point of view, the migration perceptions of people of Emirdağ, their strategies can be considered as reflections of simulacra. While the symbolic commodities of consumptions such as luxury cars, foreign plates, conspicous consumption, gold could be regarded as pertaining to simulation order, it could be stated that the Europe constructed in the imaginations of people function as Disneyland in Baudrillardian sense. The desire for reaching a Europe that is like Alice's Wonderland in the imaginations of people of Emirdag as a result of communications through simulacra, and reaching a Euorope that is completely the opposite of the imagined in fact hides the fact that the idealized Europe and the process of migration is a simulation universe and does not belong to the reality.

Within this theoretical framework and in order to analyse the migration process in the light of post-modern theories; the transformed consumption relations, the phenomenon of real and reality are examined. How the consumption patterns and expression of their life styles both verbally and in practices of the European Turks visiting the district of Emirdağ facilitate the construction of migration and Europe in the imaginations of the townspeople of Emirdağ and its surrounding villages is explained in reference to Baudrillard's simulation universe and the 
concept of simulacra. The images, which were firstly represented by materials than replaced the materials and finally became the materials themselves, are an object of prestige and identity representation in social relations. When taking the images that became materials within the contest of Emirdağ, a foreign plate attached to a luxury car may embody the idealized life style for youth in Emirdağ. From a Baudrillardian framework, the idealized Eurocentric life styles that enter into the homes through mass media, come into existance with the commodities as simulacra brought by Turkish people from European countries who visiting their hometown of Emirdağ. The symbols of desired lifestyles appeal to the Emirdağ youth while become means of prestige and status for the European Turks visiting Emirdağ.

\section{Methodology}

\section{Purpose}

The purpose of the study as follows,

- To analyze the role and the way that perceptions, aspirations and images play in actors' decision making for migration.

- In the universe of simulations, migration and factors of migration become hyperrealities and images that have lost their realities.

- By referring to Baudrillard's concepts of simulacrum and simulation, it is intended to explicate (explikeyt) whether or not and how perceptions, desires, images constructed by individuals stimulate migration.

- Within this context, the impact of direct personal communications, the communication with symbols through material ownerships, and the impact of perceptions of material symbols on individuals is analyzed.

\section{Research Design}

The main purpose of this research is to understand the dynamics of migration process in Emirdağ a district of Afyon central Turkey with forty thousand populations while two hundred thousand of its former townspeople live in several European countries. (http://Emirdağ.gen.tr/haber/Emirdağ-nuefusu-her-guen-2-kisi-azaliyor-4856, date: 12.05.2015; Bir Gurbet Türküsü Emirdağ Belgesel, 2008). Fort his purpose, a research was conducted in central Emirdağ and its surrounding villages in 2014 June and July-the months when the visitors from Europe come to Emirdağ for vacation. As a qualitative research the study that intend to analyze the perceptions of people from Emirdağ on migration, conducted 
in the frame of case study. The research design consists of five stages, the definition of the question, entering the research field, selecting the participants, collecting the data and data analysis. Case study having the basic feature of indepth analysis of small number of cases serves as an efficient background to analyze the Dynamics of migration from Emirdağ to European countries and how this process was percieved with regard to the views of individuals who are directly affected by migration (Yıldırım and Şimşek, 2011; Büyüköztürk ve et.al., 2010).

\section{Study Group}

Study group of the research is determined by criterion sample one of the type of purposive sample. In this contex, following criteria used to select the participants; people who are directly affected by migration process thorough their occupations, family ties and those who are studying in Emirdağ but strongly considering to migrate. The study group consists of 24 women and 20 men in total of 44 participants. The main criteria are that the participants are close witnesses or directly effected by the migration process, voluntary participation and confidentiality. Any information like names, communication and address information, detailed informations on occupation or any other information that would reveal their identities weren't obtained during data collection and analysis stages and participants guaranteed full anonymity. Fort his purpose codes were given to participants with the combination of the first letter of their names, their age and the first letter of their dwelling like center $-\mathrm{C}$ - or village $-\mathrm{V}$-.

Table 1: Education level and gender distribution of the study group

\begin{tabular}{|c|c|c|c|c|c|c|c|}
\hline Gender & Primary & $\begin{array}{c}\text { Highschool } \\
\text { Dropout }\end{array}$ & $\begin{array}{c}\text { Secondaryschool } \\
\text { Student }\end{array}$ & $\begin{array}{c}\text { Highschool } \\
\text { Graduate }\end{array}$ & $\begin{array}{c}\text { University } \\
\text { Student }\end{array}$ & $\begin{array}{c}\text { University } \\
\text { Graduate }\end{array}$ & Total \\
\hline Woman & 8 & & 6 & 6 & 3 & 1 & 24 \\
\hline Man & 4 & 3 & 6 & 6 & & 1 & 20 \\
\hline Total & 12 & 3 & 12 & 12 & 3 & 2 & 44 \\
\hline
\end{tabular}

Table 2: Dwelling and gender distribution of the study group

\begin{tabular}{|c|c|c|c|c|}
\hline Gender & Village & Town & Center & Total \\
\hline Woman & 9 & & 15 & 24 \\
\hline Man & 6 & 2 & 12 & 20 \\
\hline
\end{tabular}




\begin{tabular}{|c|c|c|c|c|}
\hline Total & 15 & 2 & 27 & 44 \\
\hline
\end{tabular}

\section{Means of Data Collection}

Semi-structured interview form developped by the researchers, used to collect data. This form consisted of open ended, interpretative questions. The participants were reached by snowball method and interviewes were conducted in the center of Emirdağ and its villages. Interviews took about 40 minutes and recorded and transcribed.

\section{Data Analysis}

Descriptive analysis is used to analyze the data. The findings expressed with quatations and interpreted in the light of the literature. At the first stage of descriptive analysis, a framework was determined for data analysis. The second stage the data were organized according to the framework and at the third stage the data were defined and lastly they were interpreted (Yıldırım and Şimşek, 2011).

\section{Findings and Discussions}

In this section, the findings of the research are analyzed with referans to Baudrillard's arguments on simulation universe. The results are analysed under these three topics: The future and carrier plans of the participants; dynamics of the migration process; the reality of migration to Europe vs. the imagined migration to Europe. In out contemporary world, every dimension of the social existence is in fact a complicated form of simulation, which is especially designed for the fragile reproduction of the political, economic and cultural (Luke, 1991, s.348). If migration taken into considiration within this context, it could be argued that migration is nourished with the dreams of reaching a land of prosperity, liberty and luxury and shaped by an imagined-European- lifestyle (Sahin Kütük, 2012; Marcus, 2009; Dominguez, 2014). However the previous researches reveak the fact that, the dreamed Europe and the actual social and working conditions the migrants find themselves in are completely the opposite (Şahin Kütük, 2012; Marcus, 2009; Dominguez, 2014). Hence the Simulation Theory of Baudrillard provides a unique basis for such an approach.

Each stage of simulation world has its own peculliar simulacra and values. Like all other social constructs, migration process is also shaped by these simlacra and values. In this 
context, from Baudrillard's frame work we can say that in fractal stage the approaches and practices that shape the migration process have no any value, they do not take their roots from any real culture and does not have any certain equilibrium. Thus, as a result of these approaches the migration process creates strategies that contribute to the continuation of simulation order. It could be mentioned that some of the concepts and statements that Baudrillard used for defining the fractal stage may find its reflections on the current developments of the migration process. Some of the peculiarities of the fractal stage that is functional in the analysis of migration could be as follows (Yaylac1 and Göktuna Yaylac1, 2015):

- It is not possible to talk about the existence of value anymore; the law of value does not exist

- After Orgy; the perpetual reproduction

- Operational liveliness that hides the fact that everything have disappeared but act as if still exist

- Spread of the simulacra by technological dissemination

- Discourses without any basis

- Plans and constructs for an order that doesn't exist

\section{Future Plans of the Participants}

In order to understand the future and carrier plans of the participants, their carrier plans, how they percieve their own socio-economic conditions and how can they Picture themselves in 10 years are questioned. When their answers to these questions are analyzed it became clear that the participants who have a limited opportunity of carrier and education and little prospects in terms of occupation are in the process of migration to Europe. Senior year high school students, university students and the participants who have a stable job have negative views towards migration. Five of the participants are secondary and higschool graduates with occupations like owning small size entrepreneurs, fifteen participants are senior year high school students who plan to continue threir university education. 11 participants finished their primary school education but didn't continue to high school or dropouts. They are either farmers in the rural areas or jobless. The same 11 participants whose spouses are third or fourth generation immigrants in Europe, indicate that they don't see any future in Turkey. To quote from the 18 years old female participant whose husband is from Netherlands: "I wanted to go the secondary school. It didn't happen because of my mother, father, brother." Another 
participant 30 years old female who is a primary school graduate and works as secretary, her husband is from Belgium mentions that she has no prospects of carrier here in Emirdağ. The fact that participants don't see any prospect in Emirdağ and as will be seen in the coming discussions, the illusion that the standards that could only be reached with a good education and hardwork would easily be obtained in Europe with no pain could be explained by Baudrillard's Disneyland analogy. The rosy Picture of Europe with all promising opportunities in the cognitive imaginations of individuals attracts the youth in Emirdağ. The constructed Europe, which becomes the reality itself instead of replacing it also exists in Marcus's (2009) study analyzing the Dynamics of Brezilian migration to US. Marcus uses the term "geographical imagination" in explaining the Dynamics of migration which is not solely economical basis but with basis of combination of various factors of curiosity, education, adventure, escape, family reunion (Marcus, 2009: 481). Marcus defines the concept of "geographical imagination" as "the abstract or concrete information about space that enables people to construct that space", and considers it as the most distinctive noneconomic component of factors of migration (Marcus, 2009: 481). At this point, the notion of "geographical imagination" could be functional in understanding the imagined Europe in the minds of youth in Emirdağ and the circumstances of Emirdağ at the opposite side. The US in the imaginations of Brazilians which is identified with the "life they see in the movies", adventure, liberty as in Marcus's (2009) study coincide with the imagined Europe in the minds of Emirdağ people. In his argument Marcus (2009: 487) quoting from one of the participants mention that the participant had a magical US in his childhood imagination. As will be seen in the following discussions, in the imaginations of the Emirdağ people, Europe is an enchanted land from a fairy tale, a heaven full of all opportunities. However, as mentioned before, from Baudrillardian perspective, just like the Disneyland analogy, it could be claimed that the constructed heaven functions as hiding the fact that the idealized Europe and migration does not actually exist and perpetuates Europe as a desired object.

\section{Factors Effective in the Decision Making Process for the Participants}

In the theoretical framework while discussing the postmodern discourse, it was mentioned that the main question is not what the reality is but how it is constructed. In parallel, in understanding how Europe is constructed in the minds of Emirdağ people, which reasons become important in their discourses is and how these reasons point to their imagined Europe are analysed. When the factors that are effective in their decision making for migration are 
asked, in parallel to the answers to the previous question, the main factor turned out to be the lack of job and carrier opportunities in Emirdağ. In relation to this, the participants who decide to migrate emphasise that, the idea to obtain better economic conditions, better social services were the significant in their decision-making. Additionally, the participants indicated the luxury cars, consumption patterns and especially the stories told by the individuals who come to spend their holiday from Europe as effective.

The participants whose spouses are from European countries and they migrated to Europe with them mention that theirs was a love marriage they also admit that most of the young people in Emirdağ with no education and carrier opportunities migration seem to be the only alternative and with their families' support and encouragement they choose to get married to their fellow townspeople in Europe and migrate with them. For instance female participant at the age of 17 state that: "they come in the summers for vacation. They visit us, saying your daughter at the age of marriage. For example they come from abroad to our house and talk like that. This is annoying." At this point it is also important to state that in addition to the illusive European perceptions of Emirdağ people, the Europeans of Emirdağ origin also have the same illusive perception that the authentic Turkish culture still exists in Emirdağ and it could be preserved by marrying to Emirdağ people which is a subject of another study and also could be explained through Baudrillardian framework.

One of the young female participants from her experiences mentioned those who come from Europe to Emirdağ come to ask for young girls for marriage, which is highly common in summers: "They come very often to my family this summer for arranging marriage. I tell them politely that I will continue my education. The woman only asks me "what are you going to do with education? How will you live in this dumpster?' I was very angry if this is a dumpster why they come here for vacation, don't come! They are chicks that don't like their egg shell" In the documentary movie filmed in 2008 named "Bir Gurbet Türküsü: Emirdağ" (A Ballad for a Foreign Land: Emirdağ) it was stated "gold are kept for Emirdağ when they are revealed they whet appetite of young people." To make it more concrete by examples from the interviews to quote from 30 and 36 year old female participants: "Turks here are wannabes, I'll wear short skirts or wear gold, they buy these cars there but they are indebted. They buy the car show it off here in Turkey and when they are back they start paying their debts. They are always in struggle. It is not nice but people still want to go. "For example you 
study here to become a state employee to have a future, you work hard. Then you see them they go to Europe, they do not study or work hard just with simple jobs they buy their house, car. It is hard to see that they have all with no effort."

From these statements it can be asserted that, the perceptions that education leaves you empty handed, that Emirdağ is a 'dumpster' whereas, Europe is regarded as a heaven to getaway and for emancipation is perpetuated by the cars, gold jewelleries, holiday practices and consumption patterns of those who visit Emirdağ from Europe. The fact that Emirdağ is constructed as "dumpster" by the visitors from Europe, and those of Emirdağ people regarding their town as "dark" reveals the dimensions of the delusion. The ideal Europe that is depicted in the interviews is symbolically a simulation universe where one can reach luxury and prosperity with very little or no effort. However whether or not these imaginations are based on concrete lived experiences is highly questionable. How these images are imbedded in the minds of young people in Emirdağ and how these images are tempting can be seen from the statements of the 39 year old female participant:

"Even my little daughter at the age of 10 asks 'if I should get married to go to Europe? They come here and have vacation, they go to beach but we never do that. We cannot go anywhere. They come here and live differently not like us.' Even a little kid thinks of going to Europe" 43-year-old female participant also mentions that from the young ages individuals are influenced by what they see and hear from their fellow townspeople who live in Europe with the following words:

"Now my kid goes to high school. Her grandmother already brainwashing my son don't worry if you don't continue school we'll send you to Europe. He looks at his close relatives they live in Europe, when they come back they bring fine cars, go to nice places for holidays. So he thinks 'I should go to Europe too'. Her grandmother presents the life in Europe as a salvation for him as if he is stuck in swamp." The young participants often mention that unemployment and impossibilities in Emirdağ and its villages are paradoxical with the life styles they witness in the summers. Therefore, they see migration to Europe as an alternative to hard works of farming and livestock in the villages. 
Just as individuals consume the image that the goods represent instead of the goods themselves as in the case of many brand consumer goods, in the process of migration, the desire for car in other words, the image of the life style that the car represents is being consumed. On the one hand Turks coming from Europe, express in Emirdağ their idealized Eurocentric life style with images embodied in consumer products. On the other hand their fellow towns people living in Emirdağ glorify their life style and migration to Europe. This kind of glorification and overrepresentation of Europe as a destined land is quite similar to Marcus's (2009:487) findings of his study on the Brazilians who dream of migrating to US. Marcus from referring to his interviews with participants who had lived in the US for a certain amount of time, states how individuals influence by the movies and the tales told by their relatives living in US, glorify the American Dream from the early ages. Similarly during our interviews a 21 years old male participant who went to Belgium with his wife mentioned that: "I wanted to go and see their situation there they come and show off all the time and I wanted to see what they are like in Belgium." 64 year old male participant also indicates that: "They come here with beautiful cars it is easy to buy there. Here when kids start to talk they say 'I'll go to Europe'. It is just a desire for car nothing else." From these statements it is obvious that a serious decision like starting a new life abroad takes its roots from 'desire for car' and reaching a life represented by 'desire for car'. Just like the image that the mobile phone represents is consumed instead of the material phone itself, during the migration process not the car itself but the symbols and images that the car represents are desired to be consumed as mentioned.

Just like the 46 year old male participant indicates, the young people in Emirdağ grow up with the dreams of reaching to Europe which is told to them as if it is a Wonderland: "Before they migrate, they think that they will be migrating to a dreamland. After the plane lands, they get very much surprised". As understood from the participants' remarks, even though it is known by the young people in Emirdağ that the bright picture that the people coming for vacation does not represent the truth, with the eagerness to reach prosperity in an easy way they tend to believe the bright picture and try to find the ways to reach it which ends with disappointment. What is meant by disappointment is that even though the migrants come back with a lot of luxury back homes in Europe instead of living the idealize European life. They continue to live their old small rural life. About what happens after reaching European countries, the statements of 61 years old male participant is highly striking: "I regret that he is 
gone (referring to his son). I don't like his life now. He works but his earnings are not satisfactory. Can you believe that I send clothes, food from here?" Similarly in the documentary a Ballad for a Foreign Land: Emirdağ the comments of a young man who has migrated to Belgium summarizes the situation: "Do you ever ask yourself I wish I hadn't come here? Almost every day. The realities are not like what we had thought of before. But it is perceived differently in Emirdağ". As it is seen, however the delusion in the perceptions of individuals have a significant role in their decision making process for migration, awareness of the simulation universe manifest itself during the interviews.

The hard truths in contrast to the imagined constructs often took place in the responses of the participants. For instance, a female participant at the age of 18 who migrated to Belgium stated that: "I saw from my elder sisters, they didn't like it there. When they compared Turkey they said here it is better than Belgium." Another 29 years old male participant also mentioned that: "go tell a guy to live in Istanbul instead they would see Istanbul or any other city in Turkey as dark and gloomy. Tell him go to Europe he would see it as bright. He doesn't know language can't even ask for water there but still Europe is bright to them. They go to Europe buy a car with bank loans show their car here in Emirdağ and then go back to Europe to wake up at 4 in the morning for work. I'm 29 years old never got that early in my life."

As can be seen from the responses of the participants, even if the picture of Europe drawn by the individuals spending their vacations in Emirdağ does not represent the reality, for the sake of reaching prosperity in an easy way and escape unemployment and economic constraints in Emirdağ people still believe to the imagined lands and try to reach for it. In parallel, Eastwood (1983) in his study on immigration in Venezuela discusses that, to what degree the beliefs that some regions promise better opportunities and the individual perceptions of better opportunities correspond with the realities is questionable and in many cases these beliefs are nothing but delusions (Eastwood, 1983: 452).

\section{Imagined Migration to Europe and Real Migration to Europe According to the Participants}

In order to better analyse how the migration process is perceived, the positive and negative aspects of migration to individuals and to both societies are asked. Among the positive 
aspects to individuals, the economic conditions, value given to people and liberty became prominent. Such as 43-year-old male participant regarded migration as a salvation for young people. When the negative aspects were discussed, the participants emphasized the hard working conditions, expensiveness and the problematic marriages. The paradox of the constructed Europe and the real Europe is reflected in their responses to the negative impacts of migration. For instance 53 years old male participant: "They leave here with great expectations but most of them are just disillusionments. Once they leave they cannot come back because they burn all the bridges."

Adverse economic conditions and unemployment in this case is not totally explanatory since in several interviews it was mentioned that those who have occupations such as teachers, also quit their job for Europe. For instance according to 27 years old male participant: "He is a teacher here but he saw the situation of those visiting from Europe and wanted to be like them. So he quit his job at the school and went there now he is just a non-qualified worker there." It can be inferred from this case that, the constructed ideal Europe is much more effective than the material economic conditions, when it comes to migration to Europe. Continuation of education and language learning after migrating to Europe constitutes another paradox between the imagined Europe and the real life in Europe. Referring to Sahin Kütük's (2012) fieldwork on the conditions of immigrants of Turks who work at the ethnic small enterprises of Turkish origin in Frankfurt, it was mentioned that the new comer Turkish migrants who are employed in these enterprises cannot even take language courses because of the long working hours let alone continuing higher education. One of the most significant problems of the newly arriving Turkish migrants who can only find jobs in the ethnic Turkish enterprises are the long hours of work that exceeds the legal work hour limits, low wages, not having enough time for private life and for any educational activities for self-development (Kütük, 2012: 188). Because of lack of proper language skills they could only find jobs in the ethnic enterprises, because of the constraints and hard work they couldn't have the time and energy to develop their language skills so within this vicious circle they are left no chance but to work in these adverse conditions in the same sector.

Another significant finding from the interviews is that, when the positive impacts of migration to Europe is asked the participants mention de facto universal values and concepts such as, social rights, freedom, economic prosperity however when the negative impacts are 
asked they respond with their own observations and experiences. From there it can be inferred that, when discussing the positive aspects the participants just the features of the simulation universe is repeated, namely the features of the imagined Europe. The hints of the paradox between the real and imagined Europe can be seen from the following responses to the negative and positive aspects of migration to Europe which is also the reflection of discrepancy in the minds of the participants created by this paradox. According to the 30 years old female participant quoting from her relative lives in France: "I came to these days but don't ask me how? I am at ease here for 15-20 days at most when I go back there I suffer. How we look here in Emirdağ shouldn't mislead you." Another female participant at the age of 35: "My sister while she was leaving Emirdağ she was so exited and enthusiastic. She called us as soon as she got to Belgium crying to us as here it is so disgusting, not what I've expected, not even slightly. But when you ask others who left like my sister would tell you, it so nice in Belgium, houses are so nice, etc." As mentioned in the theoretical discussions, imagined Europe which is transformed into a form of simulation universe with the positive features of liberty, prosperity and so on, functions as hiding the fact that the ideal Europe for the migrants does not exist anymore. The fact that the participants base their responses on the experienced realities for the negative aspects shows that the participants present a realistic and pragmatist attitude in their evaluations and also in a sense they are aware of the fact that the simulation universe does not represent the reality. This evaluation based on individual experiences partially affects the constructed positive image of Europe in the minds of the participants.

An additional paradoxical situation is that especially those participants who have recently migrated or will be migrating to Europe stress out the social service, health care, employment opportunities in Europe as factors for their decision making process. However when their information on the social conditions, health care services, labour market conditions and social policies of the European countries they live/will live are asked, the participants hardly give any satisfactory answers and their answers mostly based on what they hear from their relatives and friends who live in European countries. Not having solid objective information on the current conditions of the European countries and constructing an image of Europe based on what is being heard from the relatives and friends who tend to posit a rosy picture of their lives in Europe perpetuates the simulation universe and disillusionment. 64 years old male participant for instance: "It is very very wrong what they tell us. My old childhood 
friends when they come visit Emirdağ from Europe we sit at the coffee houses, cafes and they treat us with the beverages. I went there one day and go to the coffee house owned by our townsmen. Saw my friends there but they pretended they didn't see me and sneaked out. I asked another friend there what happened why did they sneak out like that? He said they don't have any money and they were ashamed because they could not offer you anything. They don't work in Europe live on unemployment benefit, and they can only spend on their vacations in Turkey. Not the same life there."

Similarly another 53 years old male participant: "They now nothing until they set their foot in Europe. After they enter the house they understand where they migrated. When they see the small old houses their disillusionment starts. They expect to see the nice big mansions, large luxurious streets and those who come from Europe in summers don't give any clue about the realities." 27 years old female participant who refers to his brother as "victim because of his friend" mentions that her brother who quitted his university education and migrated to Netherlands now regrets his decision everyday. Similar disillusionments also experienced by the Brazilians who have migrated to the US as mentioned in Marcus's (2009) study. He discusses how individuals experience the disillusionment as a result of not fulfilling their expectations of American Dream whereby everything is magical and possible and the disillusionment of arriving to a land, which is completely the opposite of what they have dreamed of (Marcus, 2009: 487).

In summary, from the experiences and responses of the participants it can be asserted that, especially the young people in Emirdağ construct an ideal Europe where they can reach all their desires, based on the tempting pictures drawn by their visitors from Europe. After migration to Europe in pursue of their dreams they face the solid truth that the bright and prosperous Europe that they dreamed of does not exist in reality. From this standpoint, the discourses on wealth and richness, the conspicuous consumption and luxury function in pretending that the fictitious order of the simulation universe, which does not refer to any truth and reality, still exists. Those individuals who still have some ties with reality, the simulation universe is meaningless, whereas those individuals who had to face the truth in one way or the other find themselves in a deep disillusionment. Trying to perceive the realities with surreal visions impacts individuals in a very powerful way. 


\section{Conclusion}

In the article, with reference to Baudrillard's simulation theory, within the framework of the migration process to Europe, it was argued that the migration process and the European Ideal as the basis of this process as a simulation universe seem to continue as if it still exists. As mentioned in the theoretical discussions, Baudrillard refers to the concept of simulacra in explaining the cultural system, “as if"ness or appearance of reality. These appearances organize the social life. Simulacra, presents the principles of reality together with the categories of how society perceives itself. The simulacra organize institutional practices in order to maintain and reproduce the status quo (Palermo, 1992). Consequently, simulacra in the form of migration from Emirdağ, provides for the reproduction of the current order of migration.

At the beginning of the discussions, it was stressed out that, the within the Baudrillardian conceptual framework, the migration perceptions of Emirdağ people can be considered as reflections of simulacra. Symbolic consumption goods and the idealized European life style identified with those commodities make Europe an object of desire for Emirdağ people as the participants often mention the richness and vanity. In other words, luxury cars, gold and conspicuous consumption as simulacra, continues the current status quo of migration and reproduce it via certain tools like marriage. Within Baudrillardian framework, in his analogy, Disneyland actually hides the fact that the outside world is a simulation. This image of Europe as paradise hides the fact that the Ideal Europe and migration per se does not exist anymore. Migration in cultural sense has disappeared; the phenomenon of migration to a prosperous free society is replaced by a migration that is homogenous with the hometown of Emirdağ itself. As a result, the Ideal Europe that was depicted in the interviews can be considered as a simulation universe in Baudrillardian sense whereby individuals reach luxury, prosperity and comfort with little or no effort.

This study explains the decision making process for migration to Europe as we know, from the Baudrillardian perspective. How the individuals who are remained in the hometown of Emirdağ perceive migration and life in Europe and how their perceptions are shaped. For future research, how the life of newly arriving immigrants change, how the discrepancy between the imagined and real Europe affects the individuals can be investigated. 


\section{References}

Adanır, O. (2010). Fikir Mimarları Dizisi-22: Baudrillard, Say Yayınları, İstanbul.

Aydoğan, İ.; Yaylacı, A.F.; Ertan, Z. (2005). Baudrillard'ın Simülasyon Evreninde Bir Simülakr Olarak Eğitim ve Eğitim Örgütleri. XIV. Ulusal Eğitim Bilimleri Kongresi, Pamukkale Üniversitesi Eğitim Fakültesi 28-30 Eylül 2005 Denizli.

Baudrillard, J. (1995). Kötülü̆̆̈̈n Şeffaflı̆̆ı, Çev: E. Abora, I.Ergüden, Ayrıntı Yayınları, İstanbul

(2008). Simgesel Değiş Tokuşve Ölüm, Çev:O.Adanır, Boğaziçi Üniversitesi Yayınları, İstanbul

(2014). Simulakrlar ve Simülasyon, Çev:O.Adanır, Doğu Batı, Ankara.

(2015). Tüketim Toplumu, Çev: A. Şenel, Ayrıntı Yayınları, İstanbul

Belek, İ. (1997), Postkapitalist Paradigmalar, Sorun Yayınları, İstanbul, s. 139-163 ve 231247

Bir Gurbet Türküsü Emirdağ, Yapım yılı: 2008, Yönetmen: Cengiz Karabekir.

Castles, S., Miller, M.J. (2008). Göçler Çă̆l, Modern Dünyada Uluslararası Göç

Hareketleri, $\quad$ B. U. Bal, İ. Akbulut (Çev.), İstanbul: İstanbul Bilgi Üniversitesi Yayınları.

Büyüköztürk, Ş., Çakmak, E., Akgün, Ö. E., Karadeniz, Ş. ve Demirel, F. (2010). Bilimsel araştırma yöntemleri. 2. Baskı. Ankara: Pegem A Yayıncılık.

Dominguez, M. V. (2014). Simulacrum and the Latin Illegal Migration in the United States.International Journal of Baudrillard Studies, 11(3).

Eastwood, D.A. (1983). Reality or Delusion: Migrant Perception of Levels of Living and Opportunity in Venezuela, 1961-1971.

http://Emirdağ.gen.tr/haber/Emirdağ-nuefusu-her-guen-2-kisi-azaliyor-4856 erişim tarihi: 12.05.2015

İlhan, S. (2013). Akışkan Toplumda Kimlik İnşası: Geçişken, Eklektik, Ben Odaklı Kimlikler, Firat Üniversitesi Sosyal Bilimler Dergisi, 23 (2), s: 233-246.

Jacobi, C. What do Baudrillard's theories of 'simulation' and 'hyper-reality' tell us about the information society?

http://essex.ac.uk/sociology/documents/pdf/ug_journal/vol7/2012SC224_ChristopherJacobi_ FINAL.pdf Date: 28.31.2015.

Kumar, K. (2010). Sanayi Sonrası Toplumdan Postmodern Topluma Çağdaş Dünyanın Yeni Kuramları, Dost Yayınevi, Ankara. 
Luke, T.W.(1991). Power and politics in hyperreality: the critical project of Jean Baudrillard. Social Science Journal, 28 (3)

Marcus, A.P. (2009). Brazillian Immigration to the United States and the Geographical Imagination, Geographical Review 99 (4), s: 481-498.

Öker, Z. (2005). Baudrillard. Kadife Karanlık, ss. 193-256, Su Yayınevi, İstanbul.

Palermo J.(1992). Dewey on the pedagogy of occupations: the social construction of the hyper-real. 10 Nisan 2011, http://www.ed.uiuc.edu/

Rosenau, P.M. (2004). Post-modernizm ve Toplum Bilimleri, Tuncay Birkan (çev.) Ankara: Bilim ve Sanat.

Sarup, M. (1996). Baudrillard ve Birtakım Kültürel Pratikler, Post-yapısalcılık ve Postmodernizm, Abdülbaki Güçlü (çev.), Ankara: Bilim ve Sanat, s.229-253.

Şahin Kütük, B. (2012). Almanya'daki Etnik Ekonomilere İşçi Göçü Olarak Ulus Ötesi Evlilikler. Hacettepe Üniversitesi Türkiyat Araştırmalar Dergisi, 16 s: 173-190. Yaylacı, A.F., Göktuna Yaylac1, (2015). F. Fraktal Evrede Eğitim: Belirsiz Bir Gelecek Ve Dengesiz Değişimler.In the process of publishing. Yıldırım, A. and Şimşek, H. (2013). Sosyal bilimlerde nitel araştırma yöntemleri. Ankara: Seçkin 